\title{
開口障害をきたした術後性上顎囊胞
}

\author{
進保朗 ${ }^{1,2)}$, 御厨 剛史 ${ }^{3)}$, 谷川 健 ${ }^{4)}$, \\ 梅野 博仁 ${ }^{1)}$ \\ 1) 久留米大学医学部耳鼻咽喉科・頭頸部外科学講座 \\ 2)社会保險田川病院耳鼻咽喉科 \\ ${ }^{3)}$ 社会医療法人天神会古賀病院 21 耳鼻咽喉科 \\ 4)公立八女総合病院病理診断科
}

術後性副鼻腔囊胞の症状は痛みを伴う煩部症状が大半を占めるが, 異胞の進展方向によって眼症状, 鼻閉等 多彩な症状をきたす。今回我々は, 輁胞が外側翼突筋を圧排し開口障害をきたしたと考えられた症例を経験し たので報告する。症例は 72 歳男性で, 開口障害を主訴に来院した。開口は約 $15 \mathrm{~mm}$ で, 単純CT検査で左上顎部 に約 $40 \times 50 \mathrm{~mm}$ の震胞性病変を認めた。同日局所麻酔下に緊急手術を施行した。手術は経鼻内視鏡下に施行し た。可及的に開空後, 開空部位の狭窄や閉塞を予防する目的で, 下鼻道鼻腔底を茎とする有茎の粘骨膜弁を用 いて開空部位を覆った。術直後にはあまり改善は認めなかったが, 手術 3 日後より徐々に開口障害は改善し始 め, 術後 1 週間後には日常生活には支障ない程度に改善した。術後 3 か月の鼻内およびCT 所見では䡬胞の再発 はなく開口障害も約 $50 \mathrm{~mm} に$ 改善し経過は良好である。

キーワード : 内視鏡下鼻内手術, 術後性上顎襄胞, 開口障害

\section{Postoperative Maxillary Cyst with Trismus: A Case Report}

\author{
Yasuro Shin ${ }^{1,2)}$, Takefumi Mikuriya ${ }^{3)}$, Ken Tanikawa ${ }^{4)}$, Hirohito Umeno ${ }^{1)}$ \\ ${ }^{1)}$ Department of Otolaryngology-Head and Neck Surgery, Kurume University School of Medicine \\ ${ }^{2}$ Department of Otolaryngology, Tagawa Hospital \\ ${ }^{3}$ Department of Otolaryngology, Koga Hospital 21 \\ ${ }^{4)}$ Yame General Hosipital, Department of Diagnostic Pathology
}

Postoperative maxillary cyst (POMC) causes cheek pain, and also results in various ocular symptoms and nasal obstruction, depending on the direction of expansion. We experienced a rare case of trismus due to a POMC that involved the lateral pterygoid muscle. The patient was a 72 -year-old man who was admitted to our hospital with a chief complaint of trismus. A CT scan showed cystic lesions of about $40 \times 50 \mathrm{~mm}$ in the left maxilla. Emergency endoscopic sinus surgery was performed under local anesthesia on the same day. After as much fenestration of the cyst as possible, the site was covered with a mucosal flap harvested from the nasal floor to prevent stenosis and obstruction of the fenestration site. Three days after surgery, symptoms gradually began to improve and the patient recovered without problems. No recurrence was found in CT performed 3 months postoperatively.

Key words : endoscopic sinus surgery, postoperative maxillary cyst, trisumus

(2018年1月 25 日受稿, 2018年6月 19 日受理) 


\section{はじめに}

術後性上顎囊胞は顔面の疼痛をきたす耳鼻科的疾患と してょく知られている。副鼻胿手術の既往があり，㚘部 から上顎洞歯龈部にかけての三叉神経第 3 枝領域の持続 する異常知覚や疼痛を訴元, さらに煩部腫脹や複視, 眼 球突出などの眼症状を伴えば比較的診断が容易な疾患で ある。今回我々は，囊胞が咀嚼筋間隙を圧排し開口障害 をきたしたと考えられた症例を経験したので報告する。

\section{症例}

症例：72歳，男性。

主訴 : 左㚘部痛, 開口障害。

既往歴: 約 30 年前に歯眼切開による上顎洞手術歴あり。 家族歷：特記事項なし。

現病歴：X年Y月Z日左頓部痛を主訴に近医歯科を受 診。投薬加療受けるが改善なくY月Z+ 5 日近医耳鼻科受 診し，開口障害を認めたため同日当科を受診した。

局所所見：1横指, 約 $15 \mathrm{~mm}$ の)開口障害を認めた (図 1 )。 鼻内所見では左総鼻道に肉芽腫様の腫瘤を認めた(図2)。 口垫内は開口障害のため十分な観察はできなかった。

画像所見：単純CT検查で左上顎部に約 $40 \times 50 \mathrm{~mm}$ の 囊胞性病変を認めた。上顎洞後壁は圧排され，骨の菲薄 化と骨欠損を認めた。冠状断では第一白歯が囊胞内に突 出していた（図3）。

血液検查：WBC $7300 / \mu \mathrm{L} （ \mathrm{Net} 70.3 \%), \quad \mathrm{CRP} 0.03 \mathrm{mg} / \mathrm{dl}$ CK 62U/1 PLT 14.7 104/ $\mu \mathrm{L}$ であり, 炎症反応の上昇は みられなかった。

診断と治療: 既往歴から術後性上顎囊胞を考えた。CT 検査では術後性上顎囊胞，歯原性病変を考えた。開口障 害をきたしており緊急手術の適応と考えたため歯科での 精査やMRI精査も困難であった。そのため, 既往歴より 術後性上顎囊胞と診断した。治療法はいずれも囊胞の開 空であるため, 緊急的な内視鏡下鼻副鼻腔手術を提案し 同意を得た。また，開口障害のため経口挿管は困難であ ると判断し，局所麻酔で手術を施行した。

手術所見: $X$ 年Y月 $Z+5$ 日, 局所麻酔下に緊急手術を 施行した。手術は経鼻内視鏡下に施行した。

20 万倍エピネフリン添加 $1 \%$ キシロカインを用いて左 鼻胿側壁から左下鼻甲介粘膜に浸潤麻酔を行った後，下 鼻甲介前端部分, 梨状口縁の後方で鼻腔底までメスで縦 切開を行った。骨膜下に下鼻甲介骨と下鼻道粘膜を剥離 挙上した。十分に下鼻甲介骨前端を露出し，上顎骨前頭 突起の鼻甲介稜から下鼻甲介をノミにて切離した。左眼 球を圧迫し, 鼻涙管の位置を確認後, ダイヤモンドバー

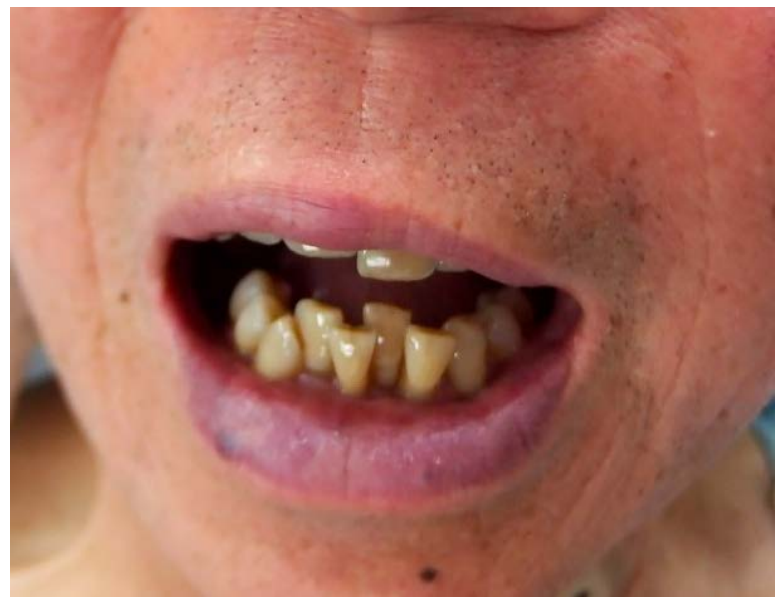

図11横指, 約 $15 \mathrm{~mm}$ の開口障害を認めた。

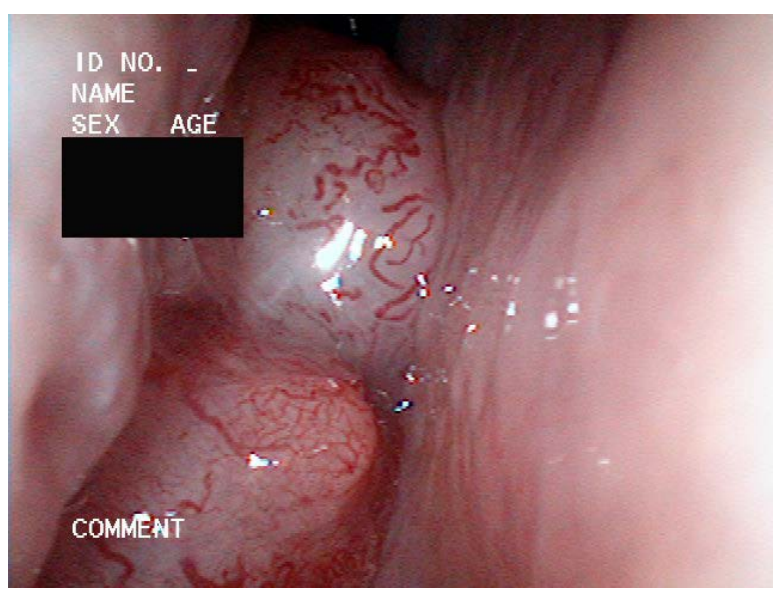

図2 左総鼻道に肉芽腫様の腫瘤を認めた。

で上顎洞内側壁を削開し，囊胞壁を同定した後に穿破し た。可及的に開空後，開空部位の狭窄や閉塞を予防する 目的で，下鼻道鼻腔底を茎とする有茎の粘骨膜弁を用い て開空部位を覆った(図4) ${ }^{1,2}$ 。生体接着剤などは用いず, 開放した囊胞にソーブサンを挿入し手術を終了とした。 出血量 $10 \mathrm{ml}$ ，手術時間 93 分であった。

術直後には開口障害の改善はほとんど認められな かった。

術後経過: 術後有害事象の出現なく, 当日 3 時間後に 帰宅とした。術翌日に鼻内のパッキングを除去した。手 術 3 日後より徐々に開口障害は改善し始め, 1 週間後, 日 常生活には支障ない程度に改善した。術後3か月の鼻内 およびCT所見では囊胞の再発はなく開口も 3 横指 $50 \mathrm{~mm}$ ほどに改善し経過は良好である（図5，6）。

\section{考察}

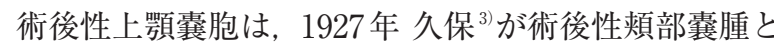




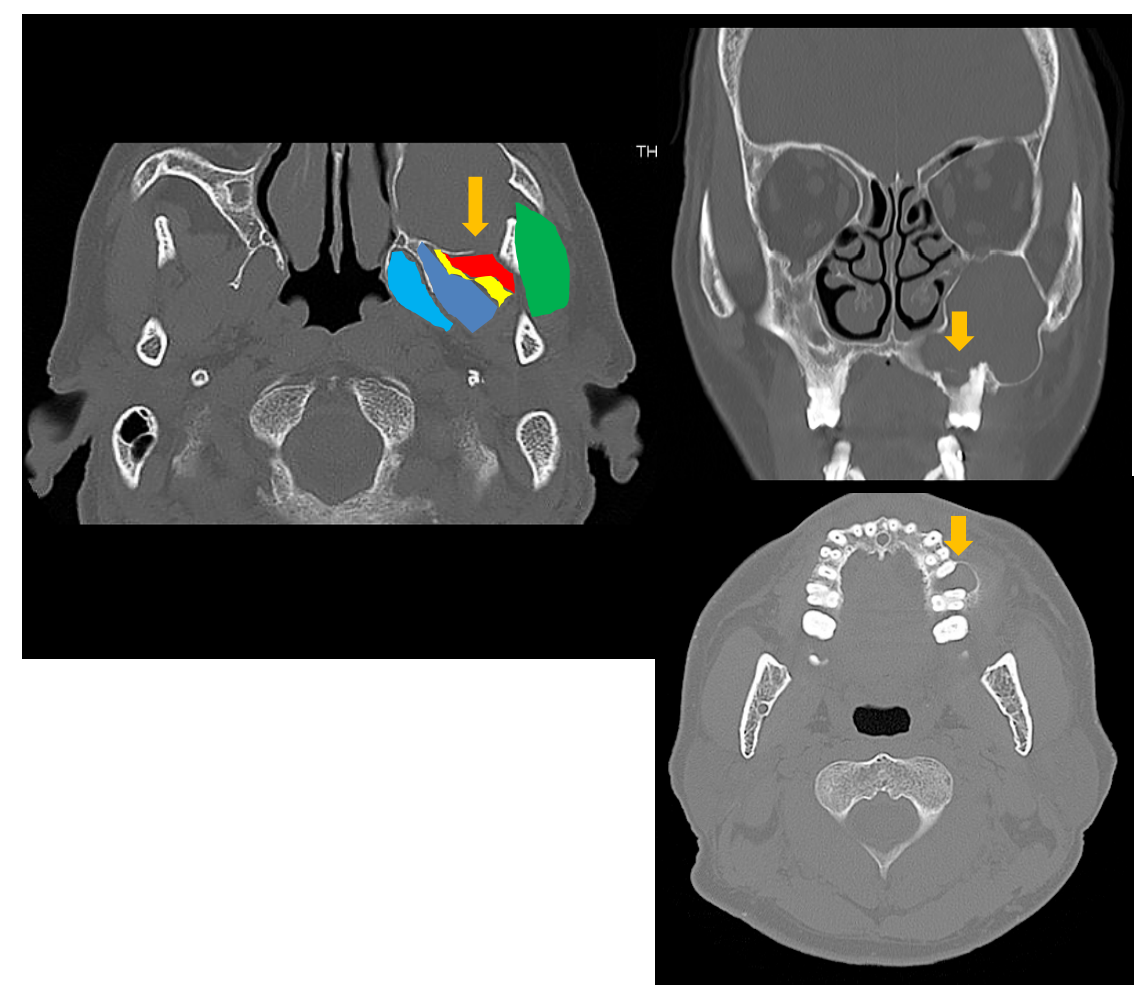

図3 術前の副鼻腔CT水平断と冠状断。水平断では, 左下鼻道に接する $40 \times 50 \mathrm{~mm}$ の震胞を認める。緑は咬筋，赤は側頭筋，黄 色は脂肪織，青は外側翼突筋，水色は内側翼突筋を示す。矢印の部位にて上顎洞後壁は広範囲に圧排され，骨の菲薄化と 骨欠損，側頭筋，咬筋，外側翼突筋への圧排と咀嚼筋間隙の脂肪織の減少を認めた。冠状断では図の矢印のごとく，第一 臼歯に歯根囊胞を疑う軟部院影を認める。

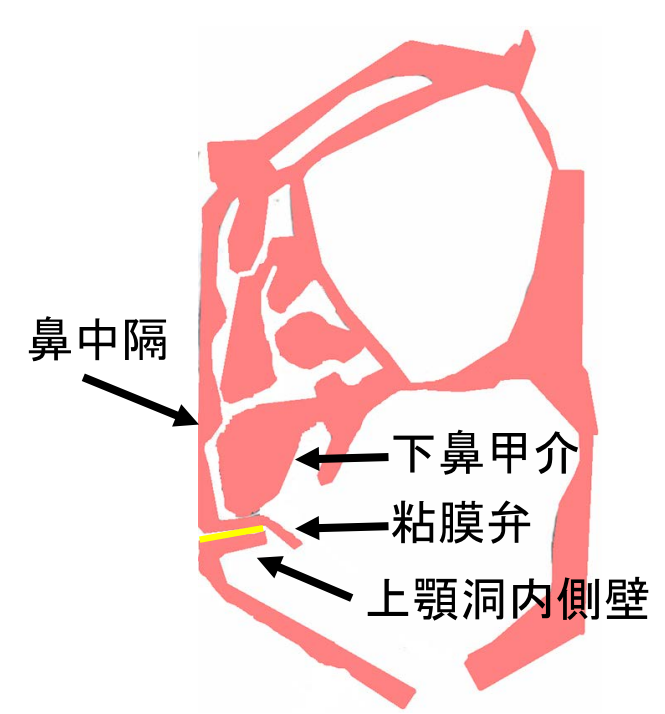

図4 左鼻腔冠状断のシェーマ。可及的に開空後, 開空部位 の狭窄や閉塞を予防する目的で，下鼻道鼻腔底を茎と する有茎の粘骨膜弁を用いて開空部位を覆った。

提唱して以来，上顎洞根本術後に高頻度にみられる疾患 で多くの報告がなされている ${ }^{4)}$ 。かし，その成因につ いてはいろいろな面から検討され一定していないが, 病

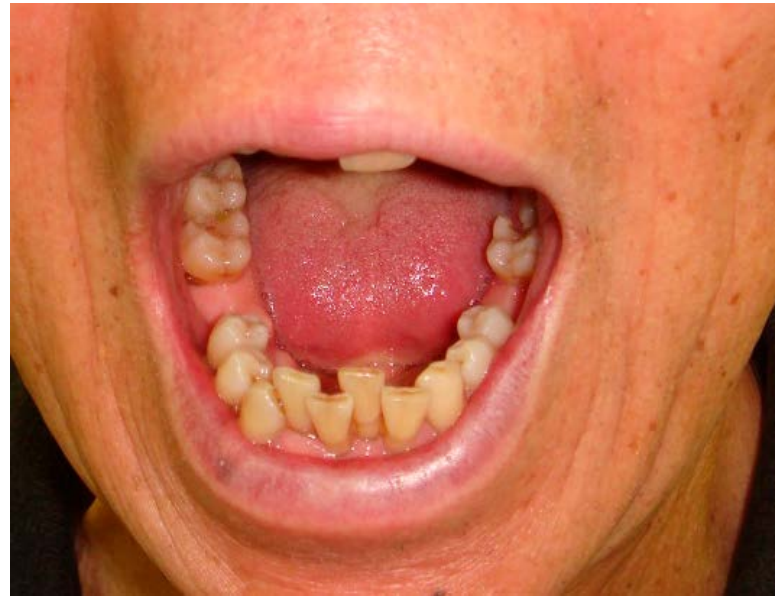

図5 開口は3横指50mmほどに改善し経過は良好である。

的粘膜で覆われた閉鎖腔が生じて拡大して発症すると言 われている5 。

本疾患は痛みを伴う頬部症状が大半を占めるが, 囊胞 の進展方向によって多彩な症状をきたし，眼症状を主と することも少なくない ${ }^{6 \sim 7)}$ 。原田ら ${ }^{8}$ は，術後性上顎洞囊 胞に対して手術を行った 126 例, 142 側において, 㚘䪱部腫 脹が 87 側 $(29 \%)$, 㚘部疼痛 73 側 $(24 \%)$, 歯痛は 41 側 


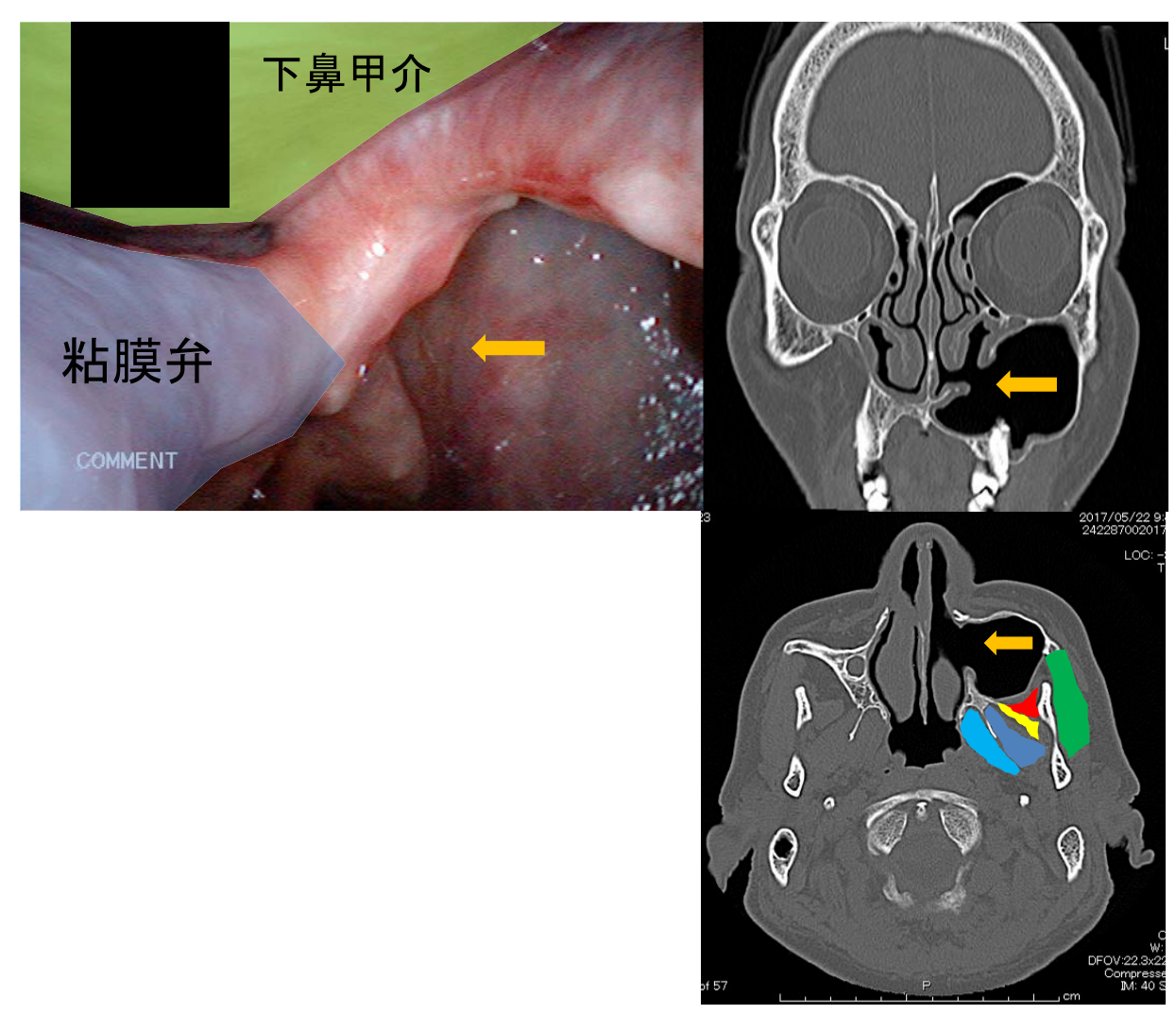

図6 術後の鼻内所見と副鼻腔CT冠状断と水平断。左下鼻道へ囊胞が開空され再閉塞は認めない。緑は咬筋, 赤は側頭筋, 黄色 は脂肪織，青は外側翼突筋，水色は内側翼突筋を示し，矢印は内視鏡写真，CT上の同部位を示している。

(13\%), 㚘部違和感 23 側 $(8 \%)$, 眼症状 30 側 $(10 \%)$, 後 鼻漏 23 側 $(8 \%)$, 鼻閉 21 側 $(7 \%)$, と報告しており, 1992 年栫 ${ }^{4)}$ は 100 例中, 煩部腫脹 84 例, 煩部痛 73 例, 流涙 12 例, 㚘部しびれ感 10 例, 歯痛 8 例, 眼球突出 6 例, 眼 痛 5 例, 複視 3 例と報告している。都築ら ${ }^{9}$ は, 煩部症状 が最多93/173例 (53.8\%) で，煩部痛 44例 (25.4\%), 㚘 部腫脹 48 例 $(27.8 \%)$, 煩部圧迫感 9 例 $(5.2 \%)$ で, その 他の症状は眼症状（視力・視野障害 15 例, 眼痛 11 例, 複 視 6 例, 流涙 6 例, 眼球突出 5 例, 眼症状が 42 例 (24.3\%), 鼻症状 (鼻閉, 鼻汁, 嗅覚障害) が23例 (13.3\%), 頭痛 17 例 $(9.8 \%)$, 歯痛 8 例 (4.6\%) であった。無症状（画 像検査で偶然発見）も8例（4.6\%）あったと報告してい る。しかし, 開口障害をきたした症例は含まれていなかっ た。開口障害を訴えた歯囊胞の報告例は少なく ${ }^{10)}$, 術後 性上顎囊胞では渉猟しえないことから，いずれでも本症 例は極めて稀であるといえる。

開口障害の分類には本邦では, 顎関節症の病態分類が 用いられている。矢谷らの報告によると ${ }^{11)}$, 咀嚼筋痛障 害 myalgia of the masticatory muscle (I型) ・顎関節痛障 害 arthralgia of the temporomandibular joint (II型) ・顎 関節円板障害temporomandibular joint disc derangement (III型) a. 復位性 with reduction b. 非復位性 without reduction ·変形性顎関節症 osteoarthrosis/osteoarthritis of the temporomandibular joint（IV型）である。顎関節 症の症状は呈していなかったことから本症例は咀嚼筋痛 障害 (I型) に分類される。囊胞が咀嚼筋痛をきたす原因 として, 主に圧排による直接刺激または囊胞感染の波及 が挙げられる。上顎囊胞の骨欠損部位の近くには開口障 害に関わる三叉神経第 3 枝の外側翼突筋神経は通常は走 行していないことを考えると，神経への直接的な圧排は 考えにくく，血液検査で炎症反応は認めなかったため強 い炎症の波及も可能性は低いと考えた。開口，閉口を担 う咀嚼筋は咬筋, 側頭筋, 外側翼突筋, および内側翼突 筋で構成されており，本症例の場合は上顎洞後壁の骨が 欠損し, 囊胞が咬筋, 側頭筋, 外側翼突筋と広範囲に圧 排していた。そのため, これらの筋が循環障害や局所の 炎症性変化を生じ開口障害をきたしたと考えられた。開 口障害が回復するまでに約 3 日を要しており，襄胞を開 放した即時に開口障害が軽減すれば圧排が主な機序であ るが, 循環障害や局所の炎症性変化などによる筋肉の障 害であったため数日間の期間を有したと推察した。

開口障害の症状が出にくいのは, 囊胞の発生様式によ るものと考えられる。福田ら ${ }^{12)}$ は襄胞の存在部位を 4 つ のtypeに分類し, 鼻腔内側壁と上顎洞の後壁について, 
骨欠損の状態からTYPE I（内側壁欠損あり,後壁欠損な し), TYPE II（内側壁欠損なし，後壁欠損あり）, TYPE III（内側壁欠損あり，後壁欠損あり）, TYPE IV（内側 壁欠損なし，後壁欠損なし）の4つのタイプに分類した。 骨欠損の状態は，鼻底から $0.5 \sim 1 \mathrm{~cm}$ 上方では，全体では TYPE Iが最も多く 44側（42\%）, IIが最も少なく9側（9\%）, そしてIIIが24側（23\%），IVが27側（26\%）であった。 鼻底から $1.0 \sim 1.5 \mathrm{~cm}$ 上方では鼻底から $0.5 \sim 1 \mathrm{~cm}$ 上方に比 べその占める割合に変化はないが，TYPE Iが47側 (45\%), IIがやや増加し 14 側（14\%)，IIIが減少して16側 (15\%), IVが27側（26\%）であった。中鼻道レベルでは， 下鼻道レベルに比べてTYPE Iが28側（27\%） と極めて 減少し, 逆にTYPE IVが52側（50\%）と増加した。一方 TYPE II, IIIはほとんど変化がなく, それぞれ9側（9\%)， 15側（14\%）であったとの報告であった。今回と同様の TYPE IIが最も少ないと報告されており, 鼻腔内側壁の欠 損がなく上顎洞後壁のみの欠損では上顎洞後壁に高い負 荷がかかった結果, 開口障害を引き起こしたと推察した。

歯原性腫瘍や襄胞と術後性上顎囊胞は鑑別が難しい が，画像診断として歯原性囊胞では，MRI上失活歯の根 尖などの内部に $\mathrm{T} 1$ 強調像で低信号, T2 強調像で高信号 を呈する内用液をもち, ガドリニウム $(\mathrm{Gd})$ 製郕による造 影で均一な比較的厚い囊胞壁を有する。術後性上顎震胞 ではMRI上T1強調像で低〜中等度, T2 強調像で高信号 を示すが, 内容が粘稠，高蛋白になると $\mathrm{T} 1$ 強調像でも高 信号に，またT2強調像では逆に信号強度が低下する ${ }^{13}$ 。

病理診断として歯原性囊胞では, 襄胞内面上皮は円柱 ないし線毛上皮が多い。囊胞壁は瘢痕組織であり，上顎 洞腺（粘液腺）を欠如している, 霊胞内容は漿液, 粘液, コレステリン結晶, ときに膿性を呈す。術後性上顎囊胞 では, 震胞内面上皮の多くは非角化性扁平上皮であるが, 上顎では円柱上皮のこともある。霊胞壁は，上皮層，肉 芽組織層, 結合組織層の 3 層にわけられる。霊胞内容は コレステリン結晶を含む ${ }^{14)}$ 。画像上でも病理学的にも困 難であることが多い。本症例では緊急手術のためMRIを 施行しておらず，囊胞壁が薄く生検も困難であった。そ のため, 既往歴より術後性上顎震胞と診断した。治療法 はいずれも囊胞の開密であるため, 実臨床では明確な区 別をせずに治療されることが多いと思われるが，他の囊 胞性変化を伴う腫瘍の可能性も念頭に置いて診断治療を すすめるべきと考えた。

$$
\text { まとめ }
$$

術後性上顎囊胞による開口障害を来した 1 例を報告 した。
本症例においては迅速に外科的治療を行うことにより 良好な結果が得られた。

開口障害の鑑別として, 術後性上顎蓑胞を鑑別に置く 必要があると考えられた。

\section{参考文献}

1）御厨剛史, 橋本 誠, 綿貫浩一, 他 : 多房性上顎囊 胞に対するナビゲーション支援の有用性について. 耳展 $2009 ; 52: 337-339$.

2）大櫛哲史: 上顎洞囊胞. 森山 宽, 春名眞一, 鴻 信 義 編：内視鏡下鼻内副鼻腔頭蓋底手術 副鼻胿疾 患から頭蓋底疾患まで，医学書院，東京；2015： p.173-183.

3）久保猪之吉：上顎洞炎根治手術後に現れたる㚘部囊 腫. 大耳鼻会報 $1927 ； 33 ： 896-897$.

4）栫 博幸, 青山 敬, 喜多村健, 他 : 䨝胞手術の臨 床統計．鼻臨床補 1992；59：43-52.

5）切替一郎：術後性上顎囊胞. 野村恭也 編. 新耳鼻 咽喉科学 第 9 版. 南山堂, 東京 ; $1998:$ p.357-362.

6) Chandler JR, Langenbrunner DJ, Stenvers ER : The pathogenesis of orbital complications in acute sinusitis. Laryngoscope $1970 ; 80: 1414-1428$.

7）唐木將行，小林隆一，長生幸司，他：視機能障害を 来した鼻副鼻腔疾患一当科 16 年間の検討一. 日鼻誌 $2000 ; 39: 113-119$

8）原田康夫, 杉本嘉朗, 田頭宣治, 他 : 術後性上顎囊 腫の統計的観察.耳鼻 $1978 ； 24: 806-811$.

9）都築建三，媣澤啓二郎，竹林宏記，他：副鼻腔囊胞 手術症例の臨床検討。日耳鼻 $2009 ； 112 ： 801-808$.

10）児島由佳，村山高章，岩坪昤子：上顎洞内に生じた 巨大な滤胞性歯襄胞の 1 例。 小児歯科学雑誌 1998 ; $36: 692-695$

11）矢谷博文：新たに改訂された日本学関節症学会によ る顎関節症の病態分類と診断基準. 日顎誌 2015;27： $76-86$.

12）福田正弘, 韓 東熙, 石橋敏夫, 他: 術後性上顎囊 胞における襄胞分布状態の検討。日耳鼻 $1988 ； 91$ ： 1395-1399.

13）金田 隆, 倉林 享 編：歯科放射線診断teaching file. 砂書房, 東京 : 2001 .

14）石川達也, 内田安信, 稗田豊治, 他 監修; 下野正 基, 野間弘康, 山根源之 編：口腔外科 - 病理診断 アトラス. 医歯薬出版, 東京 $; 1992:$ p.96-99, p.118119. 